\title{
The Practice of Tolerance among Islamic Education Teachers (IETs) through Shura in the Management of Da'wah Activities in Schools
}

\author{
Noor Azimah Surip, Khadijah Abdul Razak, Ab. Halim Tamuri, Firdaus Abdul Fatah \\ Centre of Education and Community Wellbeing, Faculty of Education, National University of Malaysia, Selangor, Malaysia \\ Email: Khadijah.razak@ukm.edu.my
}

How to cite this paper: Surip, N. A., Razak, K. A., Tamuri, A. H., \& Fatah, F. A. (2019). The Practice of Tolerance among Islamic Education Teachers (IETs) through Shura in the Management of Da'wah Activities in Schools. Creative Education, 10, 2606-2614.

https://doi.org/10.4236/ce.2019.1012188

Received: October 16, 2019

Accepted: November 24, 2019

Published: November 27, 2019

Copyright $\odot 2019$ by author(s) and Scientific Research Publishing Inc. This work is licensed under the Creative Commons Attribution International License (CC BY 4.0).

http://creativecommons.org/licenses/by/4.0/

\begin{abstract}
Tolerance is a rational, practical, and highly recommended practice in Islamic teachings. This study aspires to identify tolerance levels through shura practiced by Islamic Education Teachers (IET) across all national primary schools in Peninsular Malaysia. This study was conducted entirely using quantitative approach. A survey along with a five-point Likert scale questionnaire was distributed to 433 respondents in 4 different zones representing the state of Kedah (north zone), Kelantan (east zone), Selangor (central zone) and Johor (south zone). The results showed that the (IETs) tolerance level through shu$\mathrm{ra}$ is at high value $(\mathrm{min}=4.39$ and $\mathrm{sd}=0.383$ ). The contribution of this study is to boost the comprehension of openness through a more dynamic shura towards educators because of its capacity to promote positive shift in any school management activities.
\end{abstract}

\section{Keywords}

Tolerance, Shura, Islamic Education Teachers, Management, $D a$ wah Activities

\section{Introduction}

Tolerance is one of the mechanisms of founding a civilized, interpersonal space of interaction between people of different faiths, beliefs, and views (Agius \& Ambrosewicz 2003). Tolerance is a reciprocal process between two or more perspectives. In other words, tolerance is engendered by the conflicting feelings of being in the mood to accept or reject something for the motives of avoiding conflict; to be tolerant of something even though they disagree or dislike it. (Gibson, 2006; Sullivan \& Transue, 1999; Vogt, 1997). According to Shadi Nafisi 
(2018), a difference in thought, behaviour and tastes is one of the realities of human life which is rooted in the nature of man's creation. Meanwhile, shura is a platform where every member of the organization engages harmoniously to make an impactful and accurate decision. Nevertheless, the employment of shura is difficult to attain if the tolerance constituent has been disregarded. From the Islamic outlook, tolerance can be elucidated as the attitude and noble character implemented within the society for the goal of respecting each other within the specific limits presented in Islam (Ade, 2016).

Tolerance should also be established as a willingness to be open to others, willingness to accept criticism, willingness to respond and to believe that every single message that others convey is correct in their own way (Nurfarhana \& Khadijah, 2013). Nonetheless, tolerance in the Islamic perspective is limited in practice in certain technical matters and does not concern facets of religious beliefs or morals (Bustanul, 2016; Mazlan, 2017). In accordance with the practice of the Messenger of Allah (may peace be upon him), this attitude of tolerance was commonly showed by Prophet Muhammad through shura activities with the fundamental of encouraging, training and guiding his other associates so that they are free to engage their opinions, suggestions, and thoughts on world affairs (Abdul, 2003).

For this particular study, the tolerance practiced presented refers to its application through shura in revealing IETs' willingness to accept constructive criticism, ready to listen and accept opinions, comfortable to discuss on issues and willing to share information on tasks. Concurrently, tolerance must also be taken into consideration when it is applied among educators especially IET for the purpose of promoting excellent communication and management in schools and thus establishing a positive working surrounding (Ahmad Marzuki, 2013).

\subsection{Objective}

This study aspires to identify tolerance levels through shura practiced by Islamic Education Teachers (IETs) across all National primary schools in Peninsular Malaysia.

\subsection{Issues and Challenges}

The attitude of tolerance through shura is not widely practiced among teachers in school management. This proposal is based on the results of the study of $\mathrm{Mu}$ hammad Faizal, Rosnah, Saedah, Husaina, \& Gary (2014), who found that the competency of teachers to argue disparate views professionally during meetings was only at the satisfactory level (56.6\%). The views and ideas of the school community that were openly accepted were at the level of $(60.0 \%)$ which is high and satisfactory. Additionally, tolerance in a shura-based viewpoint is regarded as a failure because many teachers still refuse to communicate in the meetings carried out and instead these meetings frequently turned into sole briefings (Norasmah \& Rofilah 2013). This circumstance reflects the personality flaws among teachers in which its consequences will only worsen the teaching com- 
munity and their management in education (Sufean, 2004).

Meanwhile, based on preceding studies, researchers recognized that many studies on tolerance have been debated in a more focused manner on the stance and attitude of the multiple religious' views in Islamic perspectives and their feasibility in community life (Abur, 2018; Ammar, 2011; Friedmann, 2003; Hussain, 2008; Elius, Khan, Roslan, Yakub \& Kamaruzaman, 2019; Nurfarhana \& Khadijah, 2013; Saeed Akhtar et al., 2016). Most of the studies completed are also in the manifestation of literature. An empirical study on the practice of tolerance in human behaviour, work, and personal relationships are not explored in detail, the researcher proposed that it is vital for this study to examine the understanding of the tolerance concept through shura that should be regarded more dynamically and clearly through human behaviour in terms of management among IET in schools.

\section{Literature Review}

In Islam, the concept of tolerance instilled to Muslims is very practical and rational to be operated among people, so that they know and interact with each other. It is because the Quran encourages the presence of differing views in celebrating differences. This fundamental way of thinking is based on surah al-Hujurat 49: 13

O mankind! Indeed, we have created you from men and women, and we have created you as different races and tribes, so that you may know one another (and be friendly to one another).

(Translation of Abdullah Muhammad Basmeih 2006)

According to the verse, tolerance is necessary for every human being to accept the differences that emerge in terms of religion, race, culture, skin colour, or language. This is because the diversity is the sunnatullah and the nature set by Allah S.W.T. to His servant. As quoted in the Qur'an through Surah al-Syura 42:38; al-Hadid 57:25; dan al-'Araf 7:181 which suggest that every human being has the equal right to convey his beliefs either in terms of speech, conduct and attitude either in the manifestations of communication with Muslims or non-Muslims (Noraini Omar, Mohd Aderi, Mohd Isa, \& Hasnan 2014).

Studies from both domestic and foreign scholars have also proven that the application of tolerance has a tremendous effect not only on one's behavior but also on others and their work environment. Among them are the discoveries of Mas Ayu and Fatimah (2014) which prove that there is a compelling relationship between the attitude of the individual's tolerance to the assessment of excellent job performance. Fatimah wati (2012) and Bonner (2010) also found that teachers with tolerance in their personality have the advantage of overcoming a variety of work because of their open, creative and flexible stance. Likewise, Bing and Lounsbury (2000) found that openness is profoundly affected by job performance because of its willingness to learn, acquire something and accept new suggestions. Then, the results of the study by Nurul Hudani, Ma'rof Redzuan, \& 
Noor Hisham (2016) reveal that consistent open practices have a positive contribution on their work-life and quality.

An exceptional level of tolerance can only be achieved if there is mutual understanding, determination, and respect for each other in harmony. With shura, the practice of tolerance that should be practiced suggests the IETs to think outside the context of the norm, to view things from different perspectives and to be ready to face all kind of possible consequences. Such people think that it is easier to explore new experiences since they have a more flexible way of experiencing their work environment (Rothmann \& Coetzer, 2003). Meanwhile, an individual who has been adopted openness by themselves, tend to exhibit that attitude indirectly through his or her daily actions which will always be looked up to by any amateur or experienced teacher (Zahanim \& Qurratu'aini 2018). IETs should cultivate a moral code in the pursuit of healthy work culture and congruous working atmosphere.

\section{Methodology}

This study uses a quantitative research design through a survey study. The instrument employed is based on the adaptation of several shura-related theories and models, together with the literature reviews by past scholars. A total of 6 items were created to serve as instruments according to the validity and reliability of the predetermined instrument. A total of 8 panellists in the field of study participated in assessing the validity of the questionnaire, while 2 linguists were hired for the objective of validating the overall instrument. The Content Validity Ratio (CVR) method created by Lawshe (1975) was used in this study for the aim of empirically measuring the content of the paper. The CVR level value for each item considered appropriate and acceptable for the eight panels is equal to or greater than $0.75(\geq 0.75)$. Based on the analysis of the CVI (Content Validity Index), generally, the instrument shows a high value which is equal to or greater than 0.8 (CVI $\geq 0.8$ ).

Five Likert scales were used in the questionnaire, which are strongly disagree $(\mathrm{SD})$, disagree (D), moderately disagree (MD), agree (A) and strongly agree (SA). A pilot study was carried out on 153 teachers of Islamic Education (IET) from primary schools across Putrajaya. Based on the analysis, Cronbach's alpha coefficient has proven that the reliability of the questionnaire is high as the value of CVI exceeds 0.8. This value is regarded as appropriate because the best Cronbach alpha coefficient value must be equal to or greater than 0.7 (Fraenkel \& Wallen, 2008). The population for this study includes Islamic Education Teachers from primary schools throughout Peninsular Malaysia. The researcher has adopted a random sampling technique chosen from four different zones, specifically North (Kedah), South (Johor), East (Kelantan), and Central (Selangor). In this study, the total of 433 teachers of Islamic Education was involved. The data gathered were then examined descriptively based on five phases of interpretation as outlined by Nunnally and Bernstein (1994) through Table 1. 
Table 1. Table interpretations of respondents' answers.

\begin{tabular}{cc}
\hline Min Value Scores & Interpretations \\
\hline $2.01-3.00$ & Medium Low \\
$1.00-2.00$ & Low \\
$2.01-3.00$ & Relatively Low \\
$3.01-4.00$ & Relatively High \\
$4.01-5.00$ & High \\
\hline
\end{tabular}

\section{Findings}

Tolerance level through Shura practice

The findings of the study on the degree of tolerance among IETs through shura are presented in detail as Table 2.

Based on Table 2, it is evident that levels of implementation of tolerance through shura among IETs are high ( $\min 4.39$ and sd $=0.383$ ). The results show that the highest $\min$ of shura practice is $(\min =4.54$, $\mathrm{sd}=0.511)$. While the lowest $(\mathrm{min}=4.30$, sd $=0.563)$. It means that the practice of tolerance has been manifested into their attitude by allowing others to convey their ideas, celebrate difference in views, respect disparate ideas, by allowing themselves to forgive easily, quickly seek for forgiveness and being receptive towards criticism from others.

\section{Discussion}

Based on the outcome, IETs significant tolerance manifestations are observed in their willingness to allow others to come up with ideas and celebrate them despite differences of opinion. These discoveries are supported past research by Nazirah and Kamarul Azmi (2016) who found IETs to be warm, friendly, approachable and open-minded. This statement is under the opinion of Kamarul Azmi and Ab. Halim (2015) who mentioned that IETs should always be approachable, friendly, kind, and narrowing the gap between them and the students so that they can be approached through a flexible social connection. Additionally, the stance of being receptive towards criticism is also an exemplary act.

Further, the excellence of tolerance among IETs is presented through mutual respect despite having differences in opinions. This statement is supported by Nazirah and Kamarul Azmi (2016) who propose that IETs respect and understanding not only applies among them but also to other school colleagues. This atmosphere can directly form harmony and unity among members within the educational organization of the school itself (Noraini, Mohd Aderi, Mohd Isa, \& Hasnan 2014). Should the individual fails to exercise respect for each other, it does trigger not only negative perceptions but also conflict. Such issues should be avoided in order to not trigger feelings of disagreement or incompatibility that may happen between individuals or among members themselves (Rahim, 2010).

Based on the findings of the study, even though the implementation of tolerance among IETs through shura is at a very high level, researchers found that one item that refers to the tendency to forgive others is at a meagre scale. From a 
Table 2. Level of tolerance among IETs through shura implementation.

\begin{tabular}{|c|c|c|c|c|c|c|c|c|}
\hline \multirow[t]{2}{*}{ No } & \multirow{2}{*}{$\begin{array}{l}\text { Item } \\
\text { Regarding the implementation of } \\
\text { shura among IETs partners, I, }\end{array}$} & \multicolumn{5}{|c|}{ Percentage (Frequency) $\mathrm{N}=433$} & \multicolumn{2}{|c|}{$\begin{array}{l}\text { Min and Standard } \\
\text { Deviation }\end{array}$} \\
\hline & & SD & $\mathrm{D}$ & MD & A & SA & Min & Sd \\
\hline 1 & $\begin{array}{l}\text { Give space for friends } \\
\text { to convey their ideas }\end{array}$ & & & 0.7 & 43.6 & 55.7 & 4.54 & 0.511 \\
\hline 2 & Celebrate difference in views & & & 3.5 & 52.9 & 43.6 & 4.40 & 0.557 \\
\hline 3 & Respect disparate ideas & & 0.2 & 3.0 & 50.6 & 46.2 & 4.42 & 0.565 \\
\hline 4 & Easily forgive & & & 3.2 & 63.3 & 33.5 & 4.30 & 0.525 \\
\hline 5 & Easily seek for forgiveness & & & 5.1 & 58.4 & 36.5 & 4.31 & 0.563 \\
\hline 6 & Being receptive towards criticism & & & 2.3 & 57.7 & 40.0 & 4.37 & 0.530 \\
\hline & Total & & & & & & 4.39 & 0.383 \\
\hline
\end{tabular}

researcher's stance, this statement contradicts the IETs character which should have distinctive personalities, credibility and hence be an outstanding role model for the people around them (Ab. Halim, Khadijah, Mohd Aderi \& Izham 2016; Solahuddin \& Nor Azzuwal, 2017). Whereas in Islamic teaching, having a forgiving attitude is a part of the character of the righteous as quoted in Surah Ali Imran (3: 134) which means "Those who give their sustenance in times of trouble and hardship, and those who hold back their anger, and those who forgive others. And (remember) Allah loves those who do good things".

(Translation of Abdullah Muhammad Basmeih 2006)

Another trait that one should have is to forgive each other easily as it exhibits a very tolerant attitude when it comes to community relations. Other than showing empathy, this attitude is to train them to be positive and rational in realizing that no human being in the world is free from mistakes (Mohd Nasir, Siti Norlina, \& Siti Aisyah, 2015). Therefore, IETs should continuously review and reflect on their own flaws and continuously forgive others. This attitude aspires people to better recognize themselves by thinking of all the shortcomings that they have and knowing the limits to the soul in order to exhibit a more reasonable and rational attitude. Therefore, as educators and preachers, GPI should strive to persist in cultivating a high degree of self-tolerance, gentleness and forgivingness as they play a crucial role as a bil-hikmah da'wah to co-exist (Nor Amin \& Mohd Ismail, 2012). This good orientation is also one of the most desirables acts of the Prophet p.b.u.h for the objective of maintaining a good relationship among individuals.

In brief, these positive findings show that the high values portrayed by IETs through tolerance are observed in accordance with the Islamic Education Philosophy (IEP) which necessitates them to consistently spread knowledge, skills, and appreciation based on the Quran and al-Sunnah in promoting a right attitude and personality as a good servant in the world and the hereafter so that one will be able to benefit others. 


\section{Conclusion}

The impact of this study substantiates that each IET is capable of fostering tolerance through shura in a way that avoids any prejudice that may lead to lousy impression and conflict among them. Therefore, the diversity and differences that exist among members are not supposed to split them (Nazri, Nik Yusri, \& Ahmad Hidayat, 2011), but rather to become more sensitive and receptive and foster openness towards one another. Emphasis on tolerance through the implementation of shura is vital since its crucial role is not just to gather a wealth of ideas from teachers to promote the contribution of suggestions and ideas, but also to foster creativity and a culture of innovation. Even more significantly, it is intended to enhance their performance and personality especially in educational professionalism.

\section{Acknowledgements}

This research was supported by the Faculty of Education, Universiti Kebangsaan Malaysia codeGG-2019-058 and PP-FPEND-2019.

\section{Conflicts of Interest}

The authors declare no conflicts of interest regarding the publication of this paper.

\section{References}

Ab Halim, T., Khadijah Abdul, R., Mohd Aderi, C. N., \& Mohd Izham, H. (2016). Persepsi Murid-Murid Terhadap Amalan Guru Pendidikan Islam Di Malaysia. e-Jurnal Penyelidikan dan Inovasi Edisi Khas, 3, 18-40.

Abdul Monir, Y. (2003). Prinsip Pengurusan Dan Pentadbiran Menurut Al-Quran Dan Sunah DIm Syed Othman Al-Habshi \& Hamiza Ibrahim (penyunting). Pengurusan dan Pentadbiran. Kuala Lumpur: Institut Kefahaman Islam Malaysia.

Abur, H. U. (2018). Does Islam Practice Tolerance? Some Notes from Quranic Perspective (pp. 1-7)

Ade, J. (2016). Membangun Tasamuh Keberagamaan dalam Perspektif al-Quran. Jurnal Toleransi: Media Komunikasi Umat Beragama, 8, 170-187.

Agius \& Ambrosewicz, J. (2003). Towards a Culture of Tolerance and Peace. Canada: International Bureau for Children's Rights.

Ahmad Marzuki, M. (2013). Amalan Kepimpinan Islam Pengetua dan Perkaitannya Terhadap Atribut Komuniti Pembelajaran Profesioanl. Tesis Doktor Falsafah, Johor, Malaysia: Universiti Teknologi Malaysia.

Ammar, F. (2011). Religious Tolerance in Islam: Theories, Practices and Malaysia's Experiences as a Multi Racial Society. Paper Presented at Persidangan EASR 4th Conference-SECR 6th Conference Tentang Religious Tolerance and Intolerance. https://doi.org/10.31436/jia.v8i0.265

Bing, M. N., \& Lounsbury, J. W. (2000). Openness and Job Performance in U.S.-Based Japanese Manufacturing Companies. Journal of Business and Psychology, 14, 515-552. https://psycnet.apa.org/doi/10.1023/A:1022940519157 
https://doi.org/10.1023/A:1022940519157

Bonner, D. (2010). Do Individual Differences Matter? Individual Differences and Teachers' Perceptions of Physical and Social Aggression. Doctoral Dissertation, Pro-Quest Dissertations and Theses database.

Bustanul, A. (2016). Implikasi Prinsip Tasamuh (Toleransi) Dalam Interaksi Antara Umat Beragama. Jurnal Fikri, 1, 391-420.

Elius, M., Khan, I., Nor, M. R. B. M., Yusoff, M. Y. Z. B. M., \& Noordin, K. B. (2019). Islam as a Religion of Tolerance and Dialogue: A Critical Appraisal. Journal for the Study of Religions and Ideologies, 18, 96-109.

Fatimah Wati, H. (2012). Pengaruh Personaliti, Motivasi Pencapaian Dan Efikasi Kendiri Terhadap Prestasi Kerja: Pengujian Model Peramal Prestasi Kerja. Sabah, Malaysia: Universiti Malaysia Sabah.

Fraenkel, J. R., \& Wallen, N. E. (2008). How To Design and Evaluate. Ed. Ke-2. New York: McGraw-Hill.

Friedmann, Y. (2003). Tolerance and Coercion in Islam: Interfaith Relations in the Muslim Tradition. Cambridge: Cambridge University Press. https://doi.org/10.1017/CBO9780511497568

Gibson, J. L. (2006). Enigmas of Intolerance: Fifty Years after Stouffer's Communism, Conformity, and Civil Liberties. Perspectives on Politics, 4, 21-34.

Hussain, A. (2008). From Tolerance to Dialogue: A Muslim Perspective on Interfaith Dialogue with Christians. Asian Christian Review, 2, 85-97.

Kamarul Azmi, J., \& Ab. Halim, T. (2015). Membudayakan Profesionalisme Guru Pendidikan Islam yang Cemerlang dalam Pemerkasaan Pendidikan Islam dalam Cabaran Zaman (pp. 1-20). Bangi, Selangor: Persatuan Intelek Muslim Malaysia.

Lawshe, C. H. (1975). A Quantitative Approach to Content Validity. Personnel Psychology, 28, 563-575. https://doi.org/10.1111/j.1744-6570.1975.tb01393.x

Mas Ayu, O. \& Fatimah, W. H. (2014). Effect of Personality towards Effective Work Performance Review among UKM Academic Staff. Jurnal Psikologi Malaysia, 28, 63-84.

Mazlan, I. (2017). Al-Tasamuh dalam al-Quran: Satu Kajian Tafsir Tematik. In Proceeding of International Conference on Islam, Development and Social Harmony in Southest Asia (pp. 442-447). Malaysia: Universiti Kebangsaan Malaysia.

Mohd Nasir, M., Siti Norlina, M., \& Siti Aisyah, A. R. (2015). Kesihatan Mental, REBT dan Muslim. Sains Humanika, 6, 49-57.

Muhammad Faizal, A. G., Rosnah, I., Saedah, S., Husaina Banu, K., \& Gary, M. C. (2014). Keberkesanan Amalan Organisasi Pembelajaran Di Sebuah Sekolah Cemerlang Di Kuala Terengganu, Terengganu: Satu Kajian Awal. Jurnal Kurikulum \& Pengajaran Asia Pasifik, 2, 22-42.

Nafisi, S. (2018). Tolerance in Islam. HTS Teologiese Studies/Theological Studies, 74, a5145. https://doi.org/10.4102/hts.v74i3.5145

Nazirah, H., \& Kamarul, A. J. (2016). Sifat Keperibadian Guru Pendidikan Islam (GPI) Terhadap Rakan Setugas dan Pihak Atasan di Sekolah: Satu Kajian Kes. International Journal of Islamic and Civilizational Studies, 3, 85-91. https://doi.org/10.11113/umran2016.3n2.72

Nazri, M., Nik Yusri, M., \& Ahmad, H. B. (2011). Ethnic Relations in Malaysia from an Islamic Perspective. Kajian Malaysia, 29, 1-28.

Nor Amin, S. Z., \& Mohd Ismail, M. (2012). Penerapan Metode Dakwah Di Dalam Melaksanakan Proses Pengajaran Dan Pembelajaran (P \& P) Di Dalam Dan Luar Bilik 
Darjah (pp. 51-69). Le Grandeur Palm Resort, Senai, Johor: International Seminar on Teacher and Islamic Education.

Noraini, O., Mohd Aderi, C. N., Mohd Isa, H., \& Hasnan, K. (2014). The Application of Multi-Cultural Elements in the Teaching of Islamic Education. Mediterranean Journal of Social Sciences, 5, 403. https://doi.org/10.5901/mjss.2014.v5n16p403

Nunnally, J., \& Bernstein, I. (1994). Psychometric Theory (3rd ed., pp. 701). New York: McGraw-Hill.

Nurfarhana, A. R., \& Khadijah Mohd, K. H. (2013). Religious Tolerance in Malaysia: Problems and Challenges. International Journal of Islamic Thought, 3, 81-91. https://doi.org/10.24035/ijit.03.2013.007

Nurul Hudani, M. N., Ma'rof, R., \& Noor Hisham, N. (2016). Hubungan Antara Tret Personaliti Kehematan, Keterbukaan Pada Pengalaman, Ekstraversi Dan Kepatuhan Dengan Prestasi Kerja Dalam Kalangan Pemimpin Pendidik Dalam Sekolah-Sekolah Prestasi Tinggi (Hps) di Malaysia. Jurnal Psikologi Malaysia, 30, 102-112.

Rahim, M. A. (2010). Managing Conflict in Organizations. New Brunswick, NJ: Transaction Publishers.

Rothmann, S., \& Coetzer, E.P. (2003). The Big Five Personality Dimensions and Job Performance. Journal of Industrial Psychology, 29, 68-74. https://doi.org/10.4102/sajip.v29i1.88

Saeed, A., Badshah, R., Atta Ur, R., Muhammad, R., Aliya, S., \& Janas, K. (2016). The Quranic Concept of Religious Tolerance and Its Manifestation in Islamic History. Journal of Applied Environmental and Biological Sciences, 6, 136-139.

Solahuddin, A. H., \& Nor Azzuwal, K. (2017). Pembentukan Personaliti Guru Agama Sebagai Role Model dalam Masyarakat. Journal of Islamic, Social, Economics and Development, 2, 254-263.

Sufean, H. (2004). Pendidikan di Malaysia: Sejarah, Sistem dan Falsafah. Edisi ke 2. Kuala Lumpur: Dewan Bahasa dan Pustaka.

Sullivan, J. L., \& Transue, J. E. (1999). The Psychological Underpinnings of Democracy: A Selective Review of Research on Political Tolerance, Interpersonal Trust, and Social Capital. Annual Review of Psychology, 50, 625-650.

https://doi.org/10.1146/annurev.psych.50.1.625

Vogt, W. P. (1997). Tolerance \& Education: Learning to Live with Diversity and Difference. Thousand Oaks, CA: Sage Publications, Inc.

Zahanim, A., \& Qurratu'Aini, S. R. H. (2018). Konsep Mentoring dalam Kalangan Guru: Satu Penilaian Awal (pp. 557-576). e-Prosiding Persidangan Antarabangsa Sains Sosial dan Kemanusiaan, Selangor: Kolej Universiti Islam Antarabangsa Selangor. 